\title{
SOME HEMATOLOGICAL AND BIOCHEMICAL ALTERATIONS CONSEQUENT TO CONCURRENT ADMINISTRATION OF IVERMECTIN AND RAFOXANIDE IN RAMS
}

\author{
Ashraf A. EL-Ghoneimy and Ausama B. EL-Gazzar"
}

Dept. of Pharmacology and Biochemistry*, Fac.Vet. Med., Qena, South Valley University

\begin{abstract}
Ivermectin and Rafoxanide are widely used in sheep as endoectoparasiticidal and fasciolicidal drugs. The effects of ivermectin and rafoxanide as well as their concurrent use as prophylactic drugs on hematological and serum biochemical parameters were studied in 20 apparently clinically healthy rams, classified into 4 equal groups. The $1^{\text {st }}$ group was left without treatment (control). The $2^{\text {nd }}$ group was injected $s / c$ with ivermectin $\left(0.2 \mathrm{mg} \mathrm{kg}^{-1}\right)$.The $3^{\text {rd }}$ group was injected $\mathrm{s} / \mathrm{c}$ with rafoxanide $(3 \mathrm{mg}$ $\left.\mathrm{kg}^{-1}\right)$. While, the $4^{\text {th }}$ group was injected s/c with both drugs $(0.2 \mathrm{mg}$ ivermectin and $3 \mathrm{mg}$ rafoxanide $\mathrm{kg}^{-1}$ ). Blood samples were collected weekly for 2 weeks for hematological and biochemical studies. The obtained results with ivermectin treated group revealed, a significant decrease in erythrocytic count, PCV \% and Hb concentration, MCV and $\mathrm{MCHC}$. Meanwhile, significant increase in serum AST and ALT activities was recorded. The rafoxanide treated group provoked a significant decrease in leuckocytic and erythrocytic counts, $\mathrm{Hb} \%$, $\mathrm{PCV} \%, \mathrm{MCV}, \mathrm{MCH}$ and $\mathrm{MCHC} \%$ as well as serum triglycerides level. Mean while, a significant increase in serum cholesterol and LDL-c levels was reported.Moreover, the group treated S/C with both drugs, elicited a significant decrease in erythrocytic and leukocytic
\end{abstract}


counts, $\mathrm{PCV} \%, \mathrm{MCV}, \mathrm{MCH}, \mathrm{MCHC} \%$, triglyceride levels and $\mathrm{Hb} \%$. In contrast, a significant increase in AST, ALT activities, cholesterol and LDL-c levels was recorded. While, in comparison with ivermectin and rafoxanide treated groups, there was insignificant changes in albumin, blood urea nitrogen, creatinine, HDL-c and erythrocytic count. In opposite side, there was a significant increase in serum AST, ALT and LDL-c levels as compared with ivermictin and rafoxanide treated groups. Also, there was a significant decrease in $\mathrm{Hb} \%, P C V \%$, $M C V, M C H$ and $M C H C \%$. Meanwhile, a significant increase in serum cholesterol level as compared with ivermectin treated group. Moreover, there was insignificant changes in serum cholesterol and triglyceride levels, erythrocytic count, $\mathrm{Hb} \%, \mathrm{PCV} \%, \mathrm{MCH}$ and $M C H C \%$ as compared with rafoxanide treated group. In conclusion it could be concluded that hematological and biochemical alterations obtained with concurrent administration of both ivermectin and rafoxanide didn't differ greatly than those obtained with each of them when injected alone and there is no additional dangerous from this combination.

\section{INTRODUCTION}

Anthelmintics are widely used for combating or treating different helminthes infections of different animal species. Chemotherapy of parasitic infestations with a wide spectrum of activity and minimal side effects are the main objects. Ivermectin, a potent broad spectrum antiparasitic drug from macrocyclic lactone family (Lespine et al.,2006) is a mixture of two natural fermentation products of Streptomyces avermitilis.It is a 22,23-dihydroivermectin $\mathrm{B}_{1 \mathrm{a}}$ and is usually marketed as a mixture of 22,23-dihydroivermectin $\mathrm{B}_{1 \mathrm{a}}(>$ 80\%) and 22,23dihydroivermectin B 1b (Mackellar and Benchaoui, 1996). The drug 
exerts its toxic action by blocking the excitatory motor neurons in parasites which contain Gamma Amino Butyric Acid (GABA) in their nervous system (Leaning, 1981 and Barragry, 1987). Consequently, nematodes and arthropods that rely on GABA-mediated neural transmission are affected, while cestodes and trematodes which do not rely on GABA-mediated neural transmission are 'not affected (Egerton et al., 1980 and Campbell et al., 1963) Moreover; the drug has ovicidal as well as larvicidal effects (Anantaphruti et al., 1982). In sheep and goats ivermectin is highly effective against all the important pathogenic gastrointestinal nematodes, lung nematodes, nasal bots and mites (Mackellar and Benchaoui, 1996) nevertheless, the extremely potent antiparasitic activity of ivermectin is greatly averted by its frequently encountered adverse effects. Detailed studies divulged hepatitis in goats (Ali and Abu-Samra, 1987) and altered hepatic function in rams (Hassan et al., 1995) in response to ivermectin treatment. The previous side effects could represent a crimp in substantially efficient use of this drug in these species. Rafoxanide is a member of halogenated alicylanilides with potent antiparasitic activity. It has the chemical formula [3'-chloro-4' (p-chlorophenoxy)-3, 5 diiodosalicylanilide] (Adams, 1995). It is a widely used in sheep as a fasciolicidal drug. It is used for the control of Fasciola spp, Haemonchus spp (Swan, 1999) and Oestus ovis (Sanyal et al., 1986 and Swan, 1999) infestations in sheep in many parts of the world. Its fasciolicidal effect in sheep depends on the persistence of the drug in plasma. It is extensively bound to plasma protein and has a long half life about (16.6 day) as reported by Barragry, (1994). The mechanism of action of salicylanilides and their substituted phenol is through their action as uncoupler of oxidative phosphorylation 
(Adams, 1995). The drug is more effective on adult than immature flukes (Richard et al., 1990). Both ivermectin and rafoxanide are commonly concurrently used for prophylaxis and treatment of nematodes, external parasites and Fasciola infestations in sheep and there is no available data concerning the untoward effects of their concurrent use. In support of the previous concept, the present study was designed to unearth the possible side effects of ivermectin, rafoxanide and their concurrent use as prophylactic drugs that would be portrayed as undesirable biochemical and hematological effects.

\section{MATERIAL AND METHODS}

\section{1-Drugs:}

A- (Ivermectin 1\%) ${ }^{\circledR}$ is produced by Kahira Pharmaceutical and Chemical Industries Company, Cairo, Egypt. The drug is available as injectable $1 \%$, w/v sterile solution. The drug was administered subcutaneously as a single dose of $0.2 \mathrm{mg} \mathrm{kg}^{-1}$ (Garg et al., 2007).

B- (Rafoxanide) ${ }^{\circledR}$ is produced by the Egyptian Company for Chemical and Pharmaceuticals (ADWIA), the drug is available as injectable solution $7.5 \%$ each vials contains $100 \mathrm{ml}$. This drug was administered as single dose of $3 \mathrm{mg} \mathrm{kg}^{-1}$ (Adams, 1995).

\section{2-Animal:}

The present study was carried out on 2o apparently clinically healthy rams $40-50 \mathrm{~kg}$. They were housed in open yard system and fed on dry ration and barseem ad-libitum. Rams were classified into 4 equal groups. The $1^{\text {st }}$ group was left without treatment (control). The $2^{\text {nd }}$ group was injected subcutaneously with ivermectin in a dose of $0.2 \mathrm{mg} / \mathrm{kg}^{-1}$ 
(ivermectin treated group). The $3^{\text {rd }}$ group was injected subcutaneously with rafoxanide in a dosage of $3 \mathrm{mg} \mathrm{kg}^{-1}$ (rafoxanide treated group). The $4^{\text {th }}$ group was injected concurrently subcutaneously with both drugs 0.2 $\mathrm{mg} \mathrm{kg}^{-1}$ (ivermectin) and $3 \mathrm{mg} \mathrm{kg}^{-1}$ (rafoxanide) (ivermectin and rafoxanide treated group).

\section{3-Sampling:}

Two blood samples were collected by jagular puncture from animals after one and two weeks post drugs administration. The $1^{\text {st }}$ sample was collected in centrifuge tube without anticoagulant and used for separation of clear serum for biochemical analysis. The serum was separated by centrifugation at 300 r.p.m. for 15 minutes and kept frozen at $-20{ }^{\circ} \mathrm{C}$ till assayed. The $2^{\text {nd }}$ sample was collected in a test tube containing EDTA as anticoagulant and used for hematological studies.

\section{4-Analysis:}

\section{A- Biochemical analysis:-}

The serum samples were used for determination of triglycerides (Bucolo and David, 1973), total cholesterol (Mellattini, 1978), HDL-c (Clark et al., 1983), LDL-c (Friedwald et al., 1972), Albumin (Gassbaro et al., 1972), blood urea nitrogen (Putton and Crouched, 1977), creatinine (Young et al., 1975) and serum AST and ALT levels (Reitman and Frankel, 1977).

\section{B- Hematological analysis:-}

The hematological parameters $(\mathrm{Hb} \%, \mathrm{RBC}$ and $\mathrm{WBC}$ counts and PCV \%) were determined according to (Dacie and Lewis, 1994). Blood indices were calculated using these equations: 
- Mean Cell Volume $(\mathrm{MCV})=\mathrm{PCV} \% / \mathrm{RBCs} \times 10^{6} \quad \mathrm{X} 10 \quad \mathrm{fl}$

- Mean Cell Hemoglobin $(\mathrm{MCH})=\mathrm{Hb}$ g/dl/RBCs x $10^{6} \quad$ X 10pg/cell

- Mean Cell Hemoglobin Concentration $(\mathrm{MCHC})=\mathrm{Hb}$ g/dl $/$ PCV \%X100 g/dl

\section{C- Statistical analysis:-}

The results were reported as the mean \pm S.E. Statistical significance was determined using analysis of variance according to (Snedcor and Cochran, 1982). Means were compared by Least Significance Difference (LSD) test at 0.5 significance level (Steel and Torrie, 1980).

\section{RESULTS AND DISCUSSION}

\section{Hematological findings:}

Concerning the effect of $\mathrm{s} / \mathrm{c}$ administration of ivermectin, rafoxanide and their concurrent use on hemogram (Table 1) and hematological indices (Table 2) of treated rams, it was indicated that, s/c injection of ivermectin $\left(0.2 \mathrm{mg} \mathrm{kg}^{-1}\right)$ evoked non significant change in leukocytic count (after $1^{\text {st }}$ and $2^{\text {nd }}$ weeks). On other side, there was a significant decrease in erythrocytic count PCV \% and $\mathrm{Hb} \%$ (after $1^{\text {st }}$ and $2^{\text {nd }}$ weeks). The hematological indices revealed significant decrease in $\mathrm{MCH}, \mathrm{MCHC}$ and $\mathrm{MCV}$ values (after $1^{\text {st }}$ and $2^{\text {nd }}$ weeks).It was cleared that, s/c administration of rafoxanide $\left(3 \mathrm{mg} \mathrm{kg}^{-1}\right)$ elicited significant decrease in leukocytic and erythrocytic counts, $\mathrm{Hb}$ concentration and PCV $\%$ (after $1^{\text {st }}$ and $2^{\text {nd }}$ weeks). The hematological indices emphasized a significant decrease in $\mathrm{MCH}, \mathrm{MCHC}$ and $\mathrm{MCV}$ values (after $1^{\text {st }}$ and $2^{\text {nd }}$ weeks). Regarding the effect of concurrent $\mathrm{s} / \mathrm{c}$ administration of both ivermectin $\left(0.2 \mathrm{~kg}^{-1}\right)$ and rafoxanide $\left(3 \mathrm{mg} \mathrm{kg}^{-1}\right)$, it was found that there was significant decrease in leukocytic and erythrocytic counts, PCV \% and $\mathrm{Hb} \%$ ( after $1^{\text {st }}$ and $2^{\text {nd }}$ weeks) as well as $\mathrm{Hb}$ concentration (after $1^{\text {st }}$ $\overline{\text { Kafrelsheikh Vet. Med. J. Vol. } 5 \text { No. } 2 \text { (2007) }}$ 
week) as compared with the control group. While, in comparison with ivermectin and rafoxanide treated groups, there was a significant decreasee in RBCs count ( after $1^{\text {st }}$ and $2^{\text {nd }}$ weeks)as compared with ivermectin and rafoxanide treated group as well as a significant decrease in $\mathrm{Hb}$ concentration (after 1 st week) and PCV\% (after $1^{\text {st }}$ and 2 nd weeks) as compared with ivermectin treated group.In contrast,there was non significant change in erythrocytic count, $\mathrm{Hb} \%$ and $\mathrm{PCV} \%$ ( after $1^{\text {st }}$ and $2^{\text {nd }}$ weeks) as compared with rafoxanidetreated group. The hematological indices provoked significant decrease in $\mathrm{MCH}, \mathrm{MCHC}$, andMCV values (after $1^{\text {st }}$ and $2^{\text {nd }}$ weeks)while, in comparison with ivermectin treated group, In contrast,there was non significant change in $\mathrm{MCH}$ and $\mathrm{MCHC} \%$ (after $1^{\text {st }}$ and $2^{\text {nd }}$ weeks) as compared with rafoxanide treated group.

Analysis of the hematological parameters can be beneficial in assessing animal health as the hemogram and blood indices reflect the statement of the animals. From these obtained results, it was evident that s/c administration of ivermectin, rafoxanide and their concurrent use decreases the erythrocytic count and $\mathrm{Hb}$ level of treated rams. Unfortunately, our findings can not provide us with a ready explanation for ivermectin induced anemia in treated rams. It is worthwhile to contemplate proposals that enlighten us with a proper explanation. The anemia may be due to alteration of haematopoiesis as a result of hepatic pathological lesions or might be due to reduction in bile salts in small intestine since bile acids are necessary for reduction of ferric ions to ferrous easily absorbed (Kaneko et al., 1997). In the glow of the previous notion one could attribute this ivermectin induced anemia to inhibition of haemopoiesis caused by hepatic pathological lesions. This suggestion confirmed by Roey et al., (1992), Zaied (1995), Wanis (1996) and Gad 
(1998) and Zaied (2004). The authors stated that therapeutic dose of ivermectin induced various hepatic degenerative changes, cloudy swelling lymphocytic infiltration, coagulative necrosis and congestion of hepatic blood sinusoids. Moreover, this suggestion is further confirmed by Ali and Abu-Samra (1987) who reported that ivermectin treatment induced hepatitis in goats. On other side, these results are incompatible with that recorded by Asquith (1981) who stated that, i.m injection of ivermectin to adult horses at 0.2 or $0.3 \mathrm{mg} \mathrm{kg}^{-1}$ revealed no changes in hematological values. Also, these results were in disagreement with that reported by Berm and Bulman (1986) who recorded that the hematological values of cattle treated s/c with ivermectin at $0.2 \mathrm{mg} \mathrm{kg} \mathrm{kg}^{-1}$ three times with 30 days intervals showed little or no effect at 1 and 7 day after each of three treatments. These data were also, incompatible with that detected by Mahzunlar (1989) and Nakai (1990) who found that dogs treated with ivermectin revealed no abnormalities for any variable measured at hematological examination. Also, these results were disagree with Roy et al., (1992) who showed that s/c treatment of 4 clinically healthy female goats with ivermectin at a dose of $0.2 \mathrm{mg} \mathrm{kg} \mathrm{kg}^{-1}$ for 7 consecutive days revealed non significant changes in Hb levels, total erythrocytic count, total and differential leukocytic counts and blood clotting time. Moreover, these data were not coincided with Ragab (1994) who stated that, ivermectin injection $0.2 \mathrm{mg} / \mathrm{kg}^{-1}$ for 7 days in did not produce any untoward effects on $\mathrm{Hb}, \mathrm{RBCs}$, total and differential leukocytic counts. Additionally the results were in disagreement with those recorded by Wanis (1996) and who noted that male rats injected $\mathrm{s} / \mathrm{c}$ with ivomec-f and ivermectin in dose of 0.2 and $0.3 \mathrm{mg} / \mathrm{kg}^{-1}$ respectively, reflected insignificant changes on erythrocytic and leukocytic counts, $\mathrm{PCV} \%$ and $\mathrm{Hb}$ concentration along the course of the experiment. 
Concern regarding Rafoxanide induced anemia, our findings were nearly fit with El-Sayed and El-Sayed (2000) who reported that s/c treatment of ewes with rafoxanide at $3 \mathrm{mg} \mathrm{kg}-1$, induced reduction in $\mathrm{Hb}$ concentration (after $1^{\text {st }}$ week) and leukocytic and erythrocytic counts (after $2^{\text {nd }}$ week). Concerning anemia induced by concurrent use of both drugs, undoubtedly our findings obtained with other two treated groups provide us with a ready explanation and needless to say this could be attributed to augmented effect of both drugs. ]

\section{Biochemical findings :}

The results concerning tested serum parameters are summarized in Table (3). It was cleared that, s/c administration of ivermectin induced significant elevation in serum AST (after $2^{\text {nd }}$ week) and serum ALT (after $1^{\text {st }}$ and $2^{\text {nd }}$ weeks). Undoubtedly, our findings fit in with those reported by Roey et al., (1992) who found that s/c administration of ivermectin $\left(0.2 \mathrm{mg}^{\mathrm{kg}-1}\right)$ to 4 clinically healthy female goats for 7 consecutive days elicited an increase in serum AST and ALT levels. These results were also in accordance with Ragab (1994) who noted that female sheep injected with ivermectin $\left(0.2 \mathrm{mg} \mathrm{kg}^{-1}\right.$ for 7 consecutive days produced a significant increase in serum transaminases level. Moreover these results were also go parallel with Hassan et al., (1995), Zaied (1995) and Wanis (1996) and Zaied (2004). On other side, these data were in disagreement with that reported by Asquith and Kulwich (1981), Brem and Bulman (1986) and Uysal and Mahzunlar (1989). Also, s/c administration of ivermectin revealed non significant change in albumin, blood urea nitrogen, creatinine, cholesterol, triglycerides, HDLc and LDL-c. Our results are in harmony with Asquith and Kulwich (1981), Brem and Bulman (1986), Nakai et al., (1990), Wanis (1996) and Zaied (2004). 
Regarding the effect of rafoxanide treatment, it was emphasized that, s/c administration of rafoxanide $\left(3 \mathrm{mg} \mathrm{kg}^{-1}\right)$ provoked a significant increase in serum AST and ALT levels as compared with the control. Serum transaminases including AST and ALT are found in most tissues but in equal proportions. ALT occurs exclusively in the liver, but only in the cytoplasm of parenchymal cells, in contrast to AST which is equally distributed between the cytoplasm and mitochondria. Doxy (1971) stated that the level of these enzymes is increased following liver damage. Accordingly, could attribute an elevation of AST levels to the damage of hepatic cells by direct effect of the drug resulting escape of these enzymes to the plasmas. On other side, our findings were in disagreement with El-Sayed and El-Sayed (2000) who found that there was non significant change in ALT following s/c administration of rafoxanide to ewes. The present results were also in disagreement with Bulent et al., (2006) who recorded that there was non significant change in AST following oral administration of rafoxanide to cattle. Rafoxanide treatment also revealed non significant change in albumin, blood urea nitrogen, creatinine and HDL-c. These results were nearly correlate with Swan and Schroder (1981) and Shroder (1982) who stated that rafoxanide is save in sheep and cattle when administered at the recommended therapeutic dose. Also, these findings were coincided with Adams (1995) who concluded that the therapeutic dose of rafoxanide is save in cattle and sheep of all ages without any hazards. Moreover, these results were nearly similar to those obtained by El-Sayed and El-Sayed (2000). The s/c administration of rafoxanide to rams also elicited a significant increase cholesterol and LDL-c levels, meanwhile significant $\overline{\bar{K} \text { Kafrelsheikh Vet. Med. J. Vol. } 5 \text { No. } 2 \text { (2007) }}$ 
decrease in triglycerides level (after $1^{\text {st }}$ and $2^{\text {nd }}$ weeks). Our data confirmed by El-Sayed and El-Sayed (2000) who concluded that s/c administration of rafoxanide to ewes produced an elevation in total cholesterol (after $2^{\text {nd }}$ week) and LDL-c (after $1^{\text {st }}$ and $2^{\text {nd }}$ week) levels. The concurrent injection of both ivermectin $\left(0.2 \mathrm{mg}^{\mathrm{kg}-1}\right)$ and Rafoxanide $\left(3 \mathrm{mg} \mathrm{kg}^{-1}\right)$ provoked a significant increase in serum AST and ALT levels as compared with control, ivermectin and rafoxanide treated groups. This elevation might conceivable to be due to the effect of both drugs. This suggestion was confirmed by obtained data with ivermectin and rafoxanide treated groups in this study. Also, rams treated s/c with both ivermectin $\left(0.2 \mathrm{mg}^{\mathrm{kg}-1}\right)$ and rafoxanide $\left(3 \mathrm{mg} \mathrm{kg}^{-1}\right)$ concurrently showed non significant changes in albumin, blood urea nitrogen, creatinine and HDL-c levels (after $1^{\text {st }}$ and $2^{\text {nd }}$ weeks) as compared with control, ivermectin and rafoxanide treated groups. Undoubtedly, our findings obtained with ivermectin and rafoxanide treated groups provide us with a ready explanation and needless to say these results coincided with that recorded by Asquill and Kulwish (1981), Berm and Bulman (1986), Naka et al., (1990), Poul et al., (1993), Adams (1995) and El-Sayed and El-Sayed (2000) who concluded that both drugs are safe drugs. Moreover, rams treated s/c with ivermectin and rafoxanide concurrently indicated a significant decrease in serum triglycerides level as compared control and ivermectin (after $1^{\text {st }}$ and $2^{\text {nd }}$ weeks) as well as rafoxanide (after $2^{\text {nd }}$ week) treated groups. This effect could be attributed to rafoxanide as obtained in this study and confirmed by El-Sayed and ElSayed (2000). 


\section{REFERENCES}

- Adams, H. R. (1995): Veterinary Pharmacology and Therapeutics, $7^{\text {th }}$ Ed., Iowa State University, Ams, Iowa, U.S.A...

- Ali, B. H. and Abu-samra, M. T. (1987): Someclinicopathological observations in Nubian goats treated with ivermectin. Rev. Elev. Vet. Med. Pays top, 40 (2) : 141-145.

- Anantaphruti, M.; Kino, H.;Terada, M.;Ishu, A. and Snno, M. (1982): Studies on chemotherapy of parasitic helmilth xiii efficacy of ivermectin on circulating microfilaria and embryo development in female worn of Dirofilaria immitis.Japan J. Parasitol., 31(6): 517.

- Asquith, R. L.and Kulwish, R.(1981): Safety and therapeutic activity of ivermectin as an equine anthelmintic. Equine Vet .Sci, $1: 18-20$.

- Aytug, N.(1991): anthelmintic efficacy of ivermectin against natural gastrointestinal nematode infections of sheep in Bursa region and its effect on some blood values. Pendik Hayvan Hastaliklan Merkez Arastirma Enstitusu Dergisi, 22(1-2): 8693.

- Barragry, T. B. (1987): A review of pharmacology and clinical use of ivermectin. Can. Vet. J.,28:512-517.

- Barragry, T. B. (1994): Veterinary Drug Therapy, Lea and Febiger Philadelphia, Awaverly Company. 
- Brem, J. J. and Buiman, R. (1981): Safety and therapeutic activity of ivermectin as an equine anthelmintic J. Equine Vet. Sci., 1:18-20.

- Bucolo, G. and David, H. (1973): Quantitative determination of serum triglyceride by the use of enzymes. Cln. Chem., 19: 467-482.

- Bulent, E.; Ozgul, M. E. and Mustaf, K. (2006): Field trial on comparative efficacu of four fasciolicides against natural liver fluke infestation in cattle. Vet. Parasitol., 135 (3-4): 279-285.

- Campbell, W. C.; M. H. Fisher; E. O. Stapley; G. AlbersSchonberg and T. A. Jacob (1983): Ivermectin: A potent new antiparasitic agent. Science (Washington, D.C.) 221, 823.

- Clark, D. A.; Rozell, P. R. and Mosser, E. L. (1983): Evaluation of LDL-c in plasma with ultracentrifugation . Clin. Chem., 18: 499-502.

- Dacie, J. V. and Lewis, S. M. (1994): In : Practical Hematology. Churchill Living-stone, Ed., in Burgh, London, Melbaerne and New York, pp. 374 \& 438.

- Doxy, D.L. (1971): Vetrinary Clinical Pathology, $1^{\text {st }}$ Ed., London, W. B. Saunders Company, pp. 556.

- Egerton, J. R.; J. Birnbaum; L. S. Bluir; J. C. Chabala; J. Conroy; M. H. Fisher; H. Mrozik; D. A. Ostlind; C. A. Wilkins and W. C. Campbell (1980): 22, 23-dihydro avermectin $B_{1 a}$ a new antiparasitic agent. Science (Washington, D. C. ) 221,823 . 
- El-Sayed, G. R. and El-Sayed, M. G. (2000): Biochemical and hematological alterations due to administration of rafoxanide drug to ewes. Minufya Vet. J., 1(1): 35-40.

- Friedwald,W.T.; Levy, R.I. and Friedrinkson, H. (1972): Estimation of LDL-c in plasma without ultrcentrifugation. Clin. Chem., 18: 499-502.

- Gad, G. N. A. (1998): Effect of ivermectin on female fertility. MVSc. Thesis, Pharmacol. Dep., Fac. Vet. Med., Zag. Univ..

- Garg, R. G.; Umar, R. R.; Yaday, CL. And Banerjee, PS. (2007): Duration of anthelmintic effect of three formulations of ivermectin

(oral, injectable and pour-on) against multiple anthelmintic resistant Haemonchus contortus in sheep.Vet. Res. Commun., 31 (6): 749-755.

- Gassbaro, L.; Bedinelli, R. and Tomassin, G. (1972): colorimetric determination of total proteins and albumin Clin. Chem.

Acta, 36: 255.

- Hassan, M. H.; Nasser, H. M.; Abd El-Malak, G. Mary and Emara, A. Samira (1995): Altered hepatic functions consequent to ivermectin treatment in rams. Zag. Vet. Pharm. Sci., 4 (2) : 72-75.

- Kaneko,J. J.;Harvey, J. W.and Michael, L. B. (1997): Biochemistry of domestic Animals, $5^{\text {th }}$ Ed., Academic Press.

- Leaning, W. H. D. (1981): A new injectable antiparasitic agent 
for horses. Merck Sharp Dohme research laboratories. Merck Company Inc. Rahway, New Jersy.

- Lespine, A.; Alvineri, M.; Sutra, JF; Pors, L. and Chartier, C. (2006): Distribution of ivermectin in goats. Vet. Parasitol., 128 (3-4): 251-261.

- Mckellar, Q. A. and Benchaoui, H. A. (1996): Avermectins and milbemycins. J. Vet. Pharmacol. Therap., 19 : 331-3561.

- Mellatini, F. (1978): colorimetric determination of serum total cholesterol. Clin. Chem., 24: 2161-2165.

- Nakai, M.; Kawamura, N.; Katae, H. and Ohishi, S. (1990): Estimation of the safety of iovermectin in collies. J. Jap. Vet. Med. Assoc., 43 (5) : 360-366.

- Poul, JM; Verlinde, V.; Abjean, JP and Laurentie, M. (1993): Oral toxicity of weanling and adult rats invitro genotoxicity of the veterinary anthelmintic rafoxanide. J. Appl. Toxicol., 13 (2): 117-122.

- Putton, C. and Crouch, S. (1977): Determination of serum blood urea nitrogen. Anal. Chem., 464-469.

Ragab, O. A. (1994): effect of consecutive administration of ivermectin ${ }^{\mathrm{A}}$ (Ivomec) $^{\circledR}$ on liver, kidney functions and blood picture of sheep. Zag. Vet. J., 22 (5): 144-1449.

- Reitman, S. and Frankel, S. (1975): A colorimetric method for determination of serum aspartate and alanine aminotransferases.Am. J. Clin. Pathol., 28:56.

- Remez, V. I.; Zolotakhina, L. Z. And Dvsyamaikova, Yu. P. 
(1989): Toxicity of Ivermectin ${ }^{A}$ for sheep and its effect on some blood values. Vet. Bull.., 6084.

- Richard, R. J.; Bowen, F. L. and Essen, W. F. (1990): The efficacy of triclabendazole and other anthelmintics against Fasciola hepatica. In controlled studies in cattle. Vet. Record. 126: 213-216.

- Roy, A. P.; Chakraborty, A. K.; Mandol, T. K. and GHosh, R. $K$. (1992): Effect of consecutive administration of Ivermectin on hematological and certain enzyme activities of goat. Indian Vet. Med. J., !6 (3): 2.

- Sanyal, PK.; Maru, A. and Gupta, AK. (1986): The use of injectable rafoxanide against natural ovine mayiasis. Vet. Parasitol., 19 (1-2): 127-131.

- Schalm, O. W. (1975): Veterinary Hematology, $3^{\text {rd }}$ Ed., Baillier, Tindal and Cassel, London.

- Schroder, J. (1987): The safety of injectable Rafoxanide in cattle. J. South Africa Vet. Assoc., 53 (1): 29-31.

- Snedecor, G. W. and Cochran, W. G. (1982): Statistical Methods $7^{\text {th }}$ Ed., Iowa State, U.S.A..

- Steal, R. G. D. and Torrie, J. H. (1980): Principle and Proceedures of Statics. A Biochemical Approch (2 ${ }^{\text {nd }}$ Ed.) McGavous Hill Booh Company, New York, U.S.A..

- Swan,G.E.(1999): The Pharmacology of Halogenated salicylanilides and Their anthelmintic use in animals. J. South Africa Assoc., 70(2): 61-70. 
- Uysal, A. and Mahzunlar, H. (1989): Effect of Ivermectin on liver and some blood values in healthy dogs. Sagliki Veteriner Fakiilesi Dergisi (Istanbul), 15(6): 21-27.

- Wanis, S. M. (1996): Some Pharmacological studies on ivomec f, MVSc. Thesis, Pharmacol. Dep., Fac. Vet, Med., Alex. Univ..

- Young, D.; Pestaner, L. and Gibelrman, V. (1975): Colorimetric determination of total proteins and albumin. Clin. Chem, Acta, 36: 225.

- Zaied, G. M. (1995): Some pharmacological studies on ivermecti. MVSc. Thesis, Pharmacol. Dep., Fac. Vet, Med., Alex. Univ..

- Zaied, G. M. (2004): Some pharmacodynamic properties of Ivermectin in comparison with dormactin in male rats. $\mathrm{Ph} \mathrm{D}$. Thesis, Pharmacol. Dep., Fac. Vet, Med., Alex. Univ..

$$
\begin{aligned}
& \text { بعض التغير ات الدمويه و البيوكيميائيه الناتجة عن الاستخدام المنز امن } \\
& \text { للأيفر ميكتين و الر افوكسانيد في الكباش الته } \\
& \text { د./أشرف أحعد الغنيسى و د./أسامه بهجت الجزار" } \\
& \text { قسم الأدوية والكيمياء الحيوية" - كلية الطب البيطري - قنا / جامعة جنوب الوادي }
\end{aligned}
$$

يستخدم كلا من الأيفرميكتين و الرافوكسانيد على نطاق واسع لعلاج الطفيليات الخارجية والديدان الداخلية و الفثيولا في الأغنام. أجريت هذه الدراسة على عدد 20 من الكباش البالغة السليمة ظاهريا وذللك لمعرفة بعض التغيرات الدموية والكيميائية الناتجة عن استخدام كلا من هذين العقارين على حده وكذلك استخدامهما لمتزامن. قسمت هذه الكباش إلى أربعة مجموعات منساوية قوام كل مجموعة خمسة Kafrelsheikh Vet. Med. J. Vol. 5 No. 2 (2007) 
أفراد. المجموعة الأولى تركت بدون أي علاجات كمجموعة ضابطة. المجموعة الثانية نم حقنها تحت الجلد بعقار الأيفرميكتين بالجرعة العلاجية (2.20جم / كجم وزن حي ). المجموعة الثالثة تم حقنها تحت الجلد بعقار الرافوكسانيد بالجرعة العلاجية (3مجم / كجم وزن حي ). المجموعة الرابعة تم حقنها

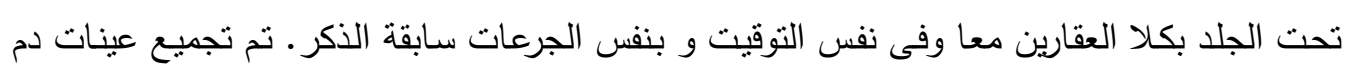

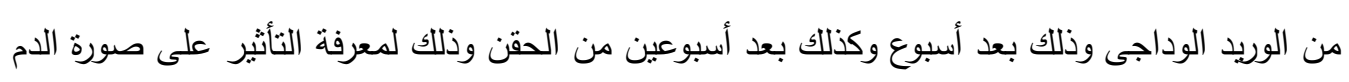

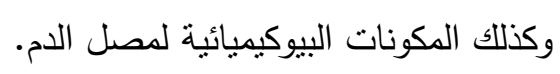
وقد أظهرت النتائج المتحصل عليها نتيجة حقن الأيفرميكتين تحت الجلد حدوث نقص معنوي

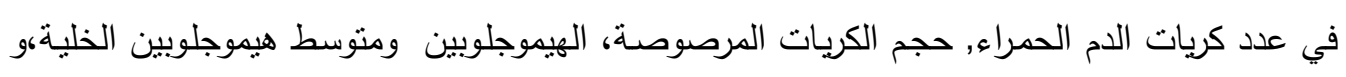

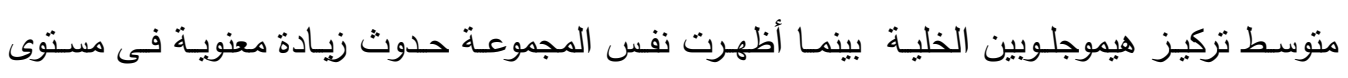
أنزيمات الألانيين و الاسبرتيت ثرانسفيريزس.

كما أظهرت المجموعة المعالجة الرافوكسانيد حدوث نقصا معنويا في عدد كربات الدم الحمراءو البيضاء, نسبة الهيموجلوبين, حجم الكريات المرصوصة, متوسط حجم الكريات ومتوسط هيموجلوبين

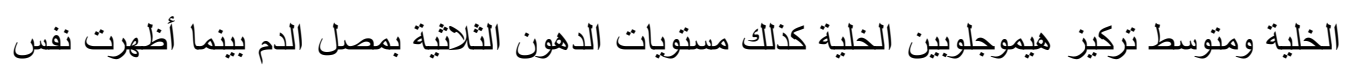

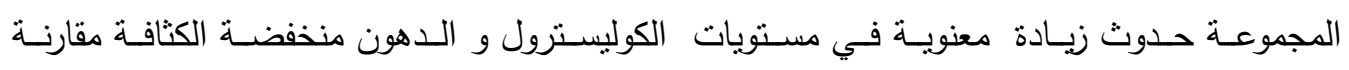
بالمجموعة الضابطة.

و قد أظهرت المجموعة المحقونة بكلا العقارين في نفس الوقت حدوث نقص معنوي في عدد كريات الدم الحمراءو البيضاء, حجم الكريات المرصوصة , منوسط حجم الكريات و الدهون الثلاثيه و الهيموجلوبين مقارنــة بالمجموعـة الضـابطة, على الجانب الآخر كـان هنـالك زيـادة معنويـة في حجم هيموجلوبين الخلية متوسط تركيز هيموجلوبين الخلية و كذلك مستويات أنزيمات الألانيين و الاسبرتيت ترانسفيريزس , الكولسترول و الدهون منخفضة الكثافة بمصل الدم مقارنة بالمجموعة الضابطة. و في مقارنة بالمجموعات المعالجة الأخرى أظهرت هذه المجموعة عدم حدوث أي تغير معنوي في مقارنة بالمجموعات المعالجة الأخرى أظهرت هذه المجموعة عدم حدوث أى تغييرات معنوية فى قيم 
مستويات الزلال، اليوريا، الكرباتتين، الدهون عاليـة الكثافة وعدد كريـات الدم الحمـراء. على الجانب الآخر كانت هناك زيادة معنوية فى مستويات أنزيمات الألاتين والأسبرتيت ترايسفيرير ، الكولستيرول والدهون منخفضة الكثافة بمصل الدم مقارنة بكل من المجموعة المعالجة بالأيفرميكتين وكذلك المجموعة المعالجة بالرانوكسابيد.

وبالمقارنـة بالمجموعة المعالجة بالأيفرفكسين كان هناك نقص معنوى فى نسبة الهيموجلوبين، حجم الكريـات المرصوصـة، متوسط حجم كريـات الـدم، متوسط هيموجلوبين الخلية ومتوسط تركيز هيموجلوبين الخليـة. وفى المقابـل كانت هنـاك زيـادة معنويـة فى مستوى الكولستنيرول بمصلـ الـم. وبمقارنـة هذه المجموعة مـع المجموعة المعالجـة بالراموكسانيد لم يكن هنـاك أى تغييرات معنويـة فىى مستويات الكولستيرول والدهون الثلاثية بمصل الدم، عدد كريات الدم الحمراء، نسبة الهيموجلوبين، حجم الكريات المرصوصة، منوسط هيموجلوبين الخلية ومتوسط تركيز هيموجلوبين الخلية. و قد خلصت هذه الدراسة إلى أن التغيرات الدموية و البيوكيميائية الناشئة عن الحقن المتزامن بكلا من عقاري الأيفرميكتين و الرافوكسانيد لا تختلف عن تلك التي نتجت عن حقن كلا من العقارين على حده , و بناء عليه لا توجد خطورة مضاعفة من ذلك الاستخدام. 